\title{
Uptake pathway for Ag bioaccumulation in three benthic invertebrates exposed to contaminated sediments
}

\author{
Hoon Yoo ${ }^{1,3}{ }^{\text {, Jung-Suk Lee }}{ }^{1}$, Byeong-Gweon Lee ${ }^{1,2, *}$, In Tae Lee ${ }^{2}$, \\ Chris E. Schlekat ${ }^{1}$, Chul-Hwan Koh ${ }^{3}$, Samuel N. Luoma ${ }^{1}$ \\ ${ }^{1}$ US Geological Survey, 345 Middlefield Road, Menlo Park, California 94025, USA \\ ${ }^{2}$ Department of Oceanography, Chonnam National University, 300 Yongbong-Dong, KwangJu 500-757, Republic of Korea \\ ${ }^{3}$ School of Earth and Environmental Sciences, Seoul National University, Seoul 151-742, Republic of Korea
}

\begin{abstract}
We exposed 3 benthic invertebrates, the clam Macoma balthica, the polychaete Neanthes arenaceodentata and the amphipod Leptocheirus plumulosus, to Ag-contaminated sediments to evaluate the relative importance of various uptake routes (sediments, porewater or overlying water, and supplementary food) for Ag bioaccumulation. Silver bioaccumulation was evaluated at 4 levels of sediment $\mathrm{Ag}\left(0.1,0,3,1,2\right.$ and $\left.3.3 \mu \mathrm{mol} \mathrm{Ag} \mathrm{g}^{-1}\right)$ and 2 levels of acid-volatile sulfide (AVS), $<0.5$ or $\sim 40 \mu \mathrm{mol} \mathrm{g}{ }^{-1}$, and compared among food treatments with or without Ag contamination, or with different food rations. L. plumulosus were incubated for $35 \mathrm{~d}$ in the Ag-contaminated sediments after 3 mo of Ag-sediment equilibration, and $M$. balthica and $N$. arenaceodentata for $19 \mathrm{~d}$ after 5 mo equilibration. Ag bioaccumulation in the 3 organisms was significantly correlated with $1 \mathrm{~N} \mathrm{HCl}$ extractable Ag concentrations (Ag-SEM: simultaneously extracted Ag with AVS) in sediments. The Ag concentrations in porewater and overlying water were greatest in the sediments with least AVS, consistent with previous studies. Nevertheless, the amphipod and clam exposed to oxic sediments $\left(<0.5 \mu \mathrm{mol} \mathrm{AVS} \mathrm{g}{ }^{-1}\right)$ accumulated amounts of Ag similar to those accumulated by organisms exposed to anoxic sediments $\left(\sim 40 \mu \mathrm{mol} \mathrm{AVS}{ }^{-1}\right)$, when Ag-SEM levels were comparable. The dissolved Ag source was important for bioaccumulation in the polychaete $N$. arenaceodentata. Amphipods fed Agcontaminated food contained $~ 1.8$-fold more tissue Ag concentrations than those fed uncontaminated food. As suggested in kinetic (DYMBAM) modeling studies, ingestion of contaminated sediments and food were the principle routes of Ag bioaccumulation by the benthic invertebrates during chronic exposure, but the relative importance of each uptake route differed among species.
\end{abstract}

KEY WORDS: Silver - Bioaccumulation - Uptake route - Acid-volatile sulfides - Macoma balthica · Neanthes arenaceodentata $\cdot$ Leptocheirus plumulosus

Resale or republication not permitted without written consent of the publisher

\section{INTRODUCTION}

Silver in aquatic environments has received attention in recent years because it is highly toxic to aquatic organisms even at trace levels, and widely distributed in the vicinity of industrialized areas (Luoma et al. 1995, Purcell \& Peters 1998, Andren \& Armstrong 1999). Silver is a geologically rare element, but is frequently found at elevated concentrations as a result of anthropogenic activities such as mining and smelting, and also due to the discharge of sewage (Bryan \& Langston 1992, Sanudo-Willhelmy \& Flegal 1992). In the water column, silver is readily adsorbed onto particles due to its high particle affinity (typical partition coefficient $K_{d}$ of $10^{4.5}$ to $10^{6}$ ); thus, sediments constitute a main repository for silver in marine and estuarine environments (Gorsuch \& Klaine 1998).

The bioavailability and acute toxicity of water-borne $\mathrm{Ag}$ is relatively well documented (Hogstrand et al. 1996, Reinfelder \& Chang 1999, Wood et al. 1999, 
Bielmyer et al. 2002, Bury \& Hogstrand 2002). For example, models are available to assess site-specific acute Ag toxicity to fishes ('biotic ligand model': Janes \& Playle 1995, Paquin et al. 2002), considering the influence of competitive cations for binding sites, $\mathrm{Ag}^{+}$ complexing anions in water and gill physiology.

In contrast, bioavailability and toxicity are poorly understood for particle-associated Ag, particularly Ag in contaminated sediments. It is established that trace metals in contaminated sediments can be transferred to and adversely affect benthic organisms (Berry et al. 1996, Hornberger et al. 2001). Sediment geochemistry, species-specific biological attributes and experimental conditions have each been shown to affect metal bioavailability to benthic invertebrates, in different experiments (Di Toro et al. 1992, Hare et al. 1994, Lee et al. 2000a, 2001, 2004, Griscom \& Fisher 2002), but the relative importance of each is not well known, nor is there agreement as to whether porewater or the sediments themselves are most important in determining metal bioavailability (Luoma et al. 1995, Hirsch 1998b, Berry et al. 1999, Lee et al. 2000a, 2001). The extent and routes of Ag transfer from sedimentary reservoirs into deposit-feeding organisms are especially poorly known.

One model that addresses bioavailability and toxicity of metals in contaminated sediments is equilibriumpartitioning as applied in the acid-volatile sulfide (AVS) normalization approach (Ankley et al. 1996). The model, and supporting studies (Ankley et al. 1996 and references therein), contends that pore waters are the primary source of metal bioavailability and hence toxicity. Metal bioavailability is greatly reduced (usually expressed as an absence of toxicity) when the molar concentration of AVS in sediments exceeds that of the simultaneously extracted metal concentration (SEM) of divalent metals (e.g. $\mathrm{Cd}, \mathrm{Cu}, \mathrm{Ni}, \mathrm{Pb}$ and $\mathrm{Zn}$ ), which can make a very insoluble metal-sulfides compound (Di Toro et al. 1992, Ankley et al. 1996, Berry et al. 1996, 1999). Therefore, the difference between molar concentrations of SEM and AVS ([SEM-AVS]) has been suggested as a tool for predicting metal toxicity in contaminated sediment (Ankley et al. 1996). Silver is mostly monovalent, so each mole of sulfide binds $2 \mathrm{~mol}$ of $\mathrm{Ag}$ to form $\mathrm{Ag}_{2} \mathrm{~S}$. Therefore [Ag-SEM]/2 is used when Ag-SEM concentration is compared with AVS concentration.

A few studies with Ag (Rodgers et al. 1997, Hirsch 1998a, Berry et al. 1999, Call et al. 1999) have shown that acute mortality does not occur when there is AVS in excess of Ag-SEM ([Ag-SEM]/2 - [AVS] < 0). For example, Berry et al. (1999) showed that mortality increased with added silver in sediments from 2 locations, but in order to be toxic, one of the sediments required more silver on a dry weight basis than the other. Acute toxicity of Ag to marine amphipods corre- lated with the $[\mathrm{Ag}-\mathrm{SEM}] / 2$ - [AVS] value or with porewater Ag concentration, but not with total Ag concentrations in the sediment. As is often the case with such experiments, exposure periods were relatively short and extreme Ag concentrations were necessary to induce acute toxicity (i.e. conditions were not suitable to evaluate chronic influences, such as dietary bioaccumulation, on bioavailability or chronic toxicity; Berry et al. 1999).

In contrast, microcosm studies or biokinetic models (Luoma et al. 1992, Wang et al. 1996, Munger \& Hare 1997, Lee et al. 2000a, 2001) have demonstrated that dietary uptake can be a major source of metal bioaccumulation by various marine invertebrates, with minor influences from porewater, under conditions conducive to chronic metal exposure. This is important with regard to Ag, because mode of exposure under chronic conditions (dietary versus dissolved route) can result in Ag toxicity to invertebrates at exposures well below those predicted by acute toxicity tests (Hook \& Fisher 2001), and can affect partitioning of Ag to different subcellular binding sites within organisms that influence the expression of toxicity (Berthet et al. 1992).

The relative importance of dissolved versus dietary Ag bioavailability in sediment-dwelling animals is not well known. Ag uptake rates from solution are among the fastest for trace elements (Reinfelder et al. 1998). Nevertheless, the modeling approaches used by Wang et al. (1996) and Griscom \& Fisher (2002) suggested that food would be an important source for Ag uptake in mussels Mytilus edulis and clams Macoma balthica, if their assimilation efficiencies of Ag from natural diets were similar to those from phytoplankton. However, it has not been tested how either of the above results would apply to Ag bioavailability from complex sediments under chronic exposure conditions. Ag partitions to sediment particles with one of the highest $K_{d}$ (partition coefficient) values among trace elements, and assimilation of Ag from sediments by bivalves, is more complex than from phytoplankton. Assimilation efficiencies from Ag-spiked sediments are typically lower than from phytoplankton (Griscom et al. 2000). Silver also forms one of the most insoluble metal sulfides $\left(\mathrm{Ag}_{2} \mathrm{~S}\right)$ in sediments (Berry et al. 1999), although Ag can be taken up from $\mathrm{Ag}_{2} \mathrm{~S}$ by mussel Mytilus edulis and clam Macoma balthica with an efficiency of $\sim 15 \%$ (Lee et al. 2000a). Finally, Ag bioavailability during chronic exposure is not known for sedmentdwelling invertebrates other than bivalves, although the transfer of metals from sediments to benthic organisms can be affected by attributes that differ widely among species, such as feeding behavior, life habits, reproductive cycles, growth and size (Cain \& Luoma 1990, Arifin \& Bendell-Young 1997, Warren et al. 1998, Lee et al. 2000a). 
Thus, while acute bioassays and modeling studies are effective approaches to forecasting potential influences on Ag bioavailability, neither have unambiguously resolved the biological or geochemical factors that might determine bioavailability during chronic exposure to contaminated sediments. In the present study we have chronically exposed 3 common estuarine species to realistically contaminated estuarine sediments containing contaminated food material and with very different geochemistry. We have directly evaluated the pathways (sediment, food and dissolved sources) by which these invertebrates accumulate Ag and compare the results to the alternative approaches. Thus, in one set of experiments, we compare the influences of biology, geochemistry and experimental conditions on the bioavailability of Ag.

We chose 3 benthic invertebrates with different biological attributes, but representative of coastal environments: the amphipod Leptocheirus plumulosus, the clam Macoma balthica, and the polychaete Neanthes arenaceodentata. These species have been widely used in many ecotoxicological studies using standard test protocols and can be easily obtained (DeWitt et al. 1992, Luoma et al. 1992, Lee et al. 2001).

\section{MATERIALS AND METHODS}

We conducted 2 sets of sediment bioaccumulation tests using the same Ag-contaminated sediment source but with different Ag-sediment equilibration times. Expt I employed the estuarine amphipod Leptocheirus plumulosus to measure Ag bioaccumulation from sediment that had been equilibrated for 3 mo. In Expt II, the bivalve Macoma balthica and the polychaete Neanthes arenaceodentata were used with sediment that had been equilibrated for 5 mo. Sediment equilibration time affects metal distribution between porewaters and particulate materials (Lee et al. 2004), and can skew the results of bioaccumulation pathway analysis, but logistical limitations required that the 2 experiments be conducted separately.

Sediment preparation. Experimental sediment that was naturally high in AVS $\left(\sim 40 \mu \mathrm{mol} \mathrm{g}^{-1}\right)$ was obtained from a mud flat near Palo Alto, San Francisco Bay, USA. The sediment was screened through $1 \mathrm{~mm}$ nylon mesh at the site and transferred to the laboratory. Mean particle size was $8.1 \varnothing$ (phi) and mean sand, silt and clay content, analyzed by the pipetting method, was $0.4,43.8$, and $55.8 \%$, respectively. Loss on ignition (LOI) was determined at $450^{\circ} \mathrm{C}$ for $4 \mathrm{~h}$ to estimate organic carbon content.

In the laboratory, several batches of sediment slurry were made by mixing $10 \mathrm{l}$ of the collected sediment with $10 \mathrm{l}$ of deoxygenated seawater. Then the slurries were spiked with an adequate amount of $30 \mathrm{mM}$ $\mathrm{AgNO}_{3}$ stock solution (prepared in Milli-Q water) to yield total Ag concentrations of $0.1,0.3,1.2,3.3 \mu \mathrm{mol}$ $\mathrm{Ag} \mathrm{g}^{-1}$ dry wt (denoted as M1, M2, M3, M4, respectively). Additionally, the sediment without Ag addition was used as a control (M0). The ranges of spiked Ag concentrations in the present study are comparable to and slightly higher than the Ag concentrations (0.01 to $0.6 \mu \mathrm{mol} \mathrm{Ag} \mathrm{g}^{-1}$ ) in the sediments of San Francisco Bay, USA (Luoma \& Phillips 1988). The Ag-sediment slurry was kept under $\mathrm{N}_{2}$-atmosphere and mixed mechanically several times a day for $1 \mathrm{wk}$. Following $1 \mathrm{wk}$ of Ag-sediment equilibration, each sediment treatment was divided into 2 portions and manipulated to achieve either $<0.5$ or $40 \mu \mathrm{mol} \mathrm{AVS} \mathrm{g}^{-1}$ dry wt (denoted as oxic and anoxic sediment, respectively). The methods for the manipulation of AVS in sediments are described in detail elsewhere (Lee et al. 2000b). These sediment slurries with a range of Ag contamination and 2 AVS levels were allowed to equilibrate for up to $5 \mathrm{mo}$ at $20^{\circ} \mathrm{C}$.

Prior to each bioaccumulation test, $200 \mathrm{ml}$ of wet sediment from each treatment was added to $1 \mathrm{l}$ glass beakers and re-equilibrated with the overlying seawater $(700 \mathrm{ml}$ ) for $5 \mathrm{~d}$. On the 5 th day of re-equilibration, the overlying seawater was replaced with clean seawater, and test organisms were added.

Test organisms. The sediment-dwelling infaunal amphipod Leptocheirus plumulosus was obtained from laboratory culture. This species has both filter-feeding and deposit-feeding habits (DeWitt et al. 1992). Amphipods were maintained in 15 psu seawater at $20^{\circ} \mathrm{C}$, and fed with ground commercial fish food, TetraMin ${ }^{\circledR}$, and the diatom Phaeodactylum tricornutum. The facultative deposit-feeding clam Macoma balthica was collected from the Palo Alto mudflat, San Francisco Bay, USA, 2 d prior to the bioaccumulation test and kept in the laboratory in 20 psu seawater at $20^{\circ} \mathrm{C}$. The deposit-feeding polychaete Neanthes arenaceodentata was obtained 3 d prior to the bioaccumulation test from a laboratory culture and maintained in $30 \mathrm{psu}$ seawater at $20^{\circ} \mathrm{C}$. The clams were supplied with $P$. tricornutum and the polychaetes with TetraMin ${ }^{\circledR}$ during the acclimation period. The salinity of the experimental seawater was adjusted by diluting $0.2 \mu \mathrm{m}$-filtered seawater (35 psu) with Milli-Q water considering each test speces' optimal salinity range.

Bioassay procedure. The amphipod bioaccumulation experiment was designed to evaluate how Ag bioaccumulation is influenced by (1) spiked Ag levels (AM0 to AM4) in the anoxic sediment, (2) AVS levels in the sediments (AM4 versus OM4), and (3) Ag contamination levels in the supplementary diet (contaminated versus uncontaminated) (Table 1). Additionally, 4 treatments in anoxic sediments (AM0, AM2, AM3, 
Table 1. Experimental design. Each treatment comprised 3 replicate containers for biological analysis and 1 for chemical analysis. $\mathrm{UF}, \mathrm{SF}_{1} \mathrm{UF}_{1 / 5}$ : uncontaminated food, Ag-spiked food, and uncontaminated food with one-fifth of regular ration, respectively; AVS: acid-volatile sulfide $(\mathrm{A}=$ anoxic, $\mathrm{O}=$ oxic); $\mathrm{AM}$, OM: anoxic and oxic metal treatments, respectively; M1-M4: spiked-Ag levels; -: no treatment

\begin{tabular}{|c|c|c|c|c|c|c|c|c|c|c|}
\hline \multirow{4}{*}{ AVS $(\mu \mathrm{mol} g$} & \multirow{2}{*}{\multicolumn{5}{|c|}{$\begin{array}{l}\text { Expt I (amphipod) } \\
\text { Leptocheirus plumulosus } \\
35 \mathrm{~d}, 15 \text { psu, } 20^{\circ} \mathrm{C}\end{array}$}} & \multicolumn{5}{|c|}{ Expt II (clam, polychaete) } \\
\hline & & & & & & \multicolumn{3}{|c|}{$\begin{array}{l}\text { Macoma balthica } \\
19 \mathrm{~d}, 20 \mathrm{psu}, 20^{\circ} \mathrm{C}\end{array}$} & \multirow{2}{*}{\multicolumn{2}{|c|}{$\begin{array}{c}\text { Neanthes arenaceodentat } \\
19 \mathrm{~d}, 30 \mathrm{psu}, 20^{\circ} \mathrm{C} \\
\text { TetraMin }{ }^{\circledR} \text {-sediment } \\
\text { mixture }\end{array}$}} \\
\hline & \multicolumn{2}{|c|}{$\begin{array}{l}\text { TetraMin }^{\circledR} \\
\text { (UF) }\end{array}$} & \multicolumn{2}{|c|}{$\begin{array}{l}\operatorname{TetraMin}^{\circledast} \\
\text { (SF) }\end{array}$} & \multirow{2}{*}{$\begin{array}{l}\text { TetraMin }^{\circledR} \\
\left.\text { (UF }_{1 / 5}\right) \\
40(\mathrm{~A})\end{array}$} & \multicolumn{2}{|c|}{$\begin{array}{l}\text { Algae } \\
\text { (UF) }\end{array}$} & \multirow{2}{*}{$\begin{array}{l}\text { Algae } \\
\text { (SF) } \\
40(\mathrm{~A})\end{array}$} & & \\
\hline & $: 40(\mathrm{~A})$ & $<0.5(\mathrm{O})$ & $40(\mathrm{~A})$ & $<0.5(\mathrm{O})$ & & $40(\mathrm{~A})$ & $<0.5(\mathrm{O})$ & & $40(\mathrm{~A})$ & $<0.5(\mathrm{O})$ \\
\hline Sediment $[\mathrm{Ag}]$ & $\left.\mathrm{mol} \mathrm{g}^{-1}\right)$ & & & & & & & & & \\
\hline M0 (Control) & AM0 & - & - & - & AM0 & AM0 & - & - & AM0 & - \\
\hline M1 (0.1) & AM1 & - & AM1 & - & - & AM1 & OM1 & AM1 & AM1 & OM1 \\
\hline M2 (0.3) & AM2 & - & AM2 & - & AM2 & AM2 & - & - & AM2 & - \\
\hline M3 (1.2) & AM3 & - & AM3 & - & AM3 & AM3 & OM3 & AM3 & AM3 & OM3 \\
\hline M4 (3.3) & AM4 & OM4 & AM4 & OM4 & AM4 & AM4 & OM4 & - & AM4 & OM4 \\
\hline
\end{tabular}

AM4) were provided with one-fifth the regular uncontaminated food ration to evaluate the influence of food ration on Ag bioaccumulation. There were 15 treatments and each had 4 replicates (Table 1); 1 replicate from each treatment was used for geochemical analysis and 3 for amphipod exposure.

To initiate the bioassay, 20 juvenile amphipods that were retained on a $250 \mu \mathrm{m}$ mesh after passing through a $450 \mu \mathrm{m}$ mesh were transferred to each replicate beaker containing the appropriate Ag-contaminated sediment and overlying water. Amphipods were exposed to experimental sediments for $35 \mathrm{~d}$ at $15 \mathrm{psu}$ and $20^{\circ} \mathrm{C}$ with a photoperiod of $16 \mathrm{~h}$ light:8 h dark. During exposure, the overlying water was continuously aerated, and half of the water was replaced with new seawater every other day, and supplementary diets were provided $1 \mathrm{~d}$ before water renewal. The food ration for each feeding was $1.5 \mathrm{mg}$ ind. ${ }^{-1}$ for the first $2 \mathrm{wk}$, and $3 \mathrm{mg}$ ind. ${ }^{-1}$ for the remaining period, in accordance with the amphipod's growth (US EPA 2001). The mean overlying water temperature, salinity, $\mathrm{pH}$ and dissolved oxygen concentration, monitored 3 times a week, were $20.4 \pm 0.17^{\circ} \mathrm{C}, 15.2 \pm 0.15 \mathrm{psu}, 7.9 \pm$ 0.11 and $7.3 \pm 0.28 \mathrm{mg} \mathrm{l}^{-1}$, respectively.

Similarly, clam and polychaete bioaccumulation studies were conducted separately and designed to evaluate how Ag bioaccumulation is influenced by (1) spiked Ag levels in the anoxic (AM0-AM4) and oxic (OM1, OM3, OM4) sediments, and (2) AVS levels (OM1, OM3, OM4 versus the respective treatment in the anoxic sediment at the same Ag level) in sediments (Table 1). Additionally, the influence of contaminated versus uncontaminated algal diets on $\mathrm{Ag}$ bioaccumulation by Macoma balthica was determined in the 2 anoxic sediments (AM1 and AM3). Clams were provided with $2.6 \mathrm{mg}$ ind..$^{-1} \mathrm{~d}^{-1}$ of algae and worms with $1 \mathrm{mg}$ ind. ${ }^{-1} \mathrm{~d}^{-1}$ of TetraMin ${ }^{\circledR}$. The bioaccu- mulation experiment for clams comprised 10 treatments and that for polychaetes 8 treatments. Each treatment had 4 replicates; 1 replicate from each treatment was used for geochemical analysis and 3 for animal incubation.

We placed 6 clams of similar size $(24 \pm 2 \mathrm{~mm}$ shell length; $79 \pm 21 \mathrm{mg}$ dry wt) or 6 individual polychaetes of similar size $(4.0 \pm 0.5 \mathrm{mg}$ dry $\mathrm{wt})$ on the surface sediment in each replicate beaker. Individuals that did not burrow into the sediment within $1 \mathrm{~h}$ were replaced with new individuals. The clams and polychaetes were exposed for $19 \mathrm{~d}$ in 20 psu (clam) or 30 psu (worm) seawater at $20^{\circ} \mathrm{C}$. All the experimental conditions and water quality data were similar to those described earlier for the amphipod experiments, except for salinities $(20.5 \pm 0.5 \mathrm{psu}$ for the clams and $30.4 \pm 0.7 \mathrm{psu}$ for the worms) and the supplementary food ration.

At the end of the experiment, test organisms were collected and depurated for 2 to $3 \mathrm{~d}$ in clean seawater. Then, the tissues were freeze-dried and digested in hot concentrated $\mathrm{HNO}_{3}$ (Brown \& Luoma 1995). The samples for geochemical analysis were taken twice, at the beginning and end of the experiment, from the beaker used for chemical analysis. Porewater samples were taken by centrifuging $(3000 \times g$ for $20 \mathrm{~min})$ $\sim 30 \mathrm{ml}$ of sediment under nitrogen atmosphere (Bufflap \& Allen 1995). The supernatant was filtered using a $0.45 \mu \mathrm{m}$ syringe filter, acidified to $\mathrm{pH} \sim 2$, and stored in a refrigerator until analysis. The overlying water was treated in the same way as the porewater, but without centrifugation. An aliquot of sediment ( $0.2 \mathrm{~g}$ dry wt) per treatment was also digested with concentrated $\mathrm{HNO}_{3}(4 \mathrm{ml})$ for near-total extraction (Brown \& Luoma 1995).

Supplementary food. The supplementary TetraMin ${ }^{\circledR}$ diet for Leptocheirus plumulosus was prepared by suspending finely ground TetraMin ${ }^{\circledR}$ in $500 \mathrm{ml}$ of 15 psu 
seawater that contained appropriate amounts of $\mathrm{AgNO}_{3}$ stock solution to yield silver concentrations of $0.3,1.0,3.6,10 \mu \mathrm{mol} \mathrm{g}{ }^{-1}$ TetraMin $^{\circledR}$. Following $1 \mathrm{wk}$ of equilibration at $4^{\circ} \mathrm{C}$, the TetraMin ${ }^{\circledR}$ settled on the bottom of a flask was freeze-dried, ground and sieved through $250 \mu \mathrm{m}$ mesh before use as food. Uncontaminated food was prepared by following the same procedure as that used for contaminated food, but without spiking Ag in the media. The Ag concentrations in the diets corresponded to $\sim 3 \times$ the sediment Ag concentrations in the AM1 to AM4 treatments fed to the amphipods in the respective treatments.

Diatoms Phaeodactylum tricornutum were also used as supplementary food. Diatoms were grown in seawater with 9 or $160 \mathrm{nM} \mathrm{Ag}$ for $1 \mathrm{wk}$, which yielded Ag concentrations similar to those of the sediment $(0.04 \pm$ $0.02 \mu \mathrm{mol} \mathrm{g}{ }^{-1}$ dry wt algae for AM1 and $0.6 \pm 0.3 \mu \mathrm{mol}$ $\mathrm{g}^{-1}$ for AM3 [ $\left.\mathrm{N}=6\right]$ ). During the $19 \mathrm{~d}$ exposure, clams in AM1 and AM3 were fed $20 \mathrm{ml}$ of Ag-enriched algae $\left(=2.6 \mathrm{mg}\right.$ dry wt ind.$\left.^{-1}\right)$ per feeding occasion. The former algal diet was provided in the AM1 treatment and the latter in the AM3 treatment. Algal diets for uncontaminated food treatments were cultured without Ag spiking in the culture media.

For Neanthes arenaceodentata, $30 \mathrm{mg}$ of ground TetraMin $^{\circledR}$ was mixed with $2 \mathrm{~g}$ of Ag-contaminated sediment from each treatment and equilibrated for $4 \mathrm{~d}$ at $4^{\circ} \mathrm{C}$. Since only a single food type was added to each sediment treatment in the $N$. arenaceodentata test chambers, the effect of food treatment on Ag bioaccumulation could not be evaluated.

Chemical and data analysis. The experimental containers and glassware used for chemical analysis and sample storage were acid-washed, followed by soaking in deoxygenated Milli-Q water. Sediment AVS was analyzed by the cold-acid $(1 \mathrm{~N} \mathrm{HCl})$ purge-and-trap technique described by Boothman \& Helmstetter (1992). The concentrations of Ag in the porewater and overlying water were analyzed with a GFAAS (graphite furnace atomic absorption spectrometer) after $10 \times$ dilution with Milli-Q water. Silver concentrations in the sediment and tissue extracts were determined by flame-AAS with appropriate dilution. Procedural blanks and NBS (National Bureau of Standards, USA) oyster tissue (standard reference material 1566a) were used for quality control and assurance. Mean recovery for $\mathrm{Ag}$ was $96.4 \pm 1.0 \%(\mathrm{~N}=6)$, and the method detection limit (MDL) for Ag in porewater was $7.4 \mathrm{nM}$.

The Ag-SEM and AVS values used for comparison with tissue Ag data were the geometric mean of values determined from sediments sampled at time $t=0$ (initial) and $t=f$ (final). Unpaired $t$-tests were conducted to compare tissue Ag concentrations between different treatments (oxic versus anoxic, contaminated versus uncontaminated food, and food rations). The statistical significance was set at $\alpha=0.05$, unless otherwise noted.

\section{RESULTS}

\section{Sediment geochemistry}

The AVS concentrations in Expt I decreased by 38 to $57 \%$ during $35 \mathrm{~d}$ incubation and those in Expt II decreased by 66 to $88 \%$ during 19 d incubation (Table 2). The decrease in AVS was probably due to the combination of bioirrigation/bioturbation by the test organisms and oxidation of sediments by constant aeration of the overlying water. The greater decrease in AVS with the clams and polychaetes was probably due to their larger sizes and greater ventilating activities compared to that of amphipods in Expt I. The organic matter content (as LOI) was constant among all sediment treatments $(9.5 \pm 0.6 \%)$. In both Expts I and II, Ag extracted by weak acid (1N HCl) with AVS (AgSEM) in the sediments generally changed little over the $35 \mathrm{~d}$ (Expt I) or $19 \mathrm{~d}$ (Expt II) exposure periods. The exception was at the highest sediment Ag treatments (AM4, OM4) where Ag-SEM decreased by 15 to $52 \%$ during the incubation period. These changes in SEM over time probably reflected the transition of Ag to more recalcitrant sediment phases (Lee et al. 2004). This is supported by 2 lines of evidence. First, Ag concentrations extracted by near-total digestion with concentrated $\mathrm{HNO}_{3}$ were similar between the samples collected at the beginning and end of each sediment incubation. Second, the Ag-SEMs determined at the end of Expt I was similar to those determined at the beginning of Expt II (Table 2). Expt II was initiated at the completion of Expt I with the same sediment source, that had been aging continuously.

The molar [Ag-SEM]/2 - [AVS] values for all the anoxic sediments (AM0 to AM4) were negative; i.e. the AVS concentrations in these treatments were greater than Ag-SEM (Table 2). The [Ag-SEM]/2 - [AVS] values in the oxic sediments (OM1, OM3, OM4) were close to or greater than 0. Porewater and overlying water Ag concentrations in most treatments were below the detection limits $(7.4 \mathrm{nM})$. Detectable amounts of dissolved Ag were present in high-Ag sediments (AM4 and OM4) in Expt I (Table 3). In those treatments, the porewater and overlying water-Ag concentrations were higher in oxic sediment (OM4) than in anoxic sediment (AM4), and also higher at the beginning than at the end of incubation. Ag concentrations in the overlying water were generally higher in sediment treatments provided with contaminated diets than those treated with uncontaminated diets, possibly due to desorption from contaminated TetraMin ${ }^{\circledR}$. 
Table 2. Near-total [Ag], [Ag-SEM], [AVS], and [Ag-SEM]/2 - [AVS] in sediments $\left(\mu \mathrm{mol} \mathrm{g}{ }^{-1}\right.$ sediment; mean \pm SD) at initiation $(t=0)$ and end $(t=f)$ of Expts I and II. SEM: simultaneously extracted metal concentrations; Near-total Ag: [Ag] extracted with near-total digestion by concentrated $\mathrm{HNO}_{3}$ for $1 \mathrm{wk}$ (means of $t=0$ and $t=f$ values). Ag-SEM values are mean chemical data from treatments with different Ag levels in supplementary food; see Table 1 for experimental design and treatment designations

\begin{tabular}{|c|c|c|c|c|c|c|c|}
\hline \multirow[t]{2}{*}{ Treatment } & \multirow[t]{2}{*}{ Near-total Ag } & \multicolumn{2}{|c|}{ Ag-SEM } & \multicolumn{2}{|c|}{ AVS } & \multicolumn{2}{|c|}{$[\mathrm{Ag}-\mathrm{SEM}] / 2-[\mathrm{AVS}]$} \\
\hline & & $t=0$ & $t=f$ & $t=0$ & $t=f$ & $t=0$ & $t=f$ \\
\hline \multicolumn{8}{|c|}{ Expt I (amphipod) } \\
\hline AM0 & $0.01 \pm 0.00$ & $0.00 \pm 0.00$ & $0.00 \pm 0.00$ & $32.9 \pm 1.7$ & $14.0 \pm 5.3$ & -32.9 & -14.0 \\
\hline AM1 & $0.09 \pm 0.01$ & $0.03 \pm 0.01$ & $0.04 \pm 0.00$ & $26.8 \pm 1.4$ & $15.3 \pm 1.9$ & -26.8 & -15.3 \\
\hline AM2 & $0.32 \pm 0.04$ & $0.12 \pm 0.02$ & $0.11 \pm 0.03$ & $22.6 \pm 0.1$ & $14.0 \pm 2.3$ & -22.5 & -14.0 \\
\hline AM3 & $1.26 \pm 0.02$ & $0.68 \pm 0.02$ & $0.66 \pm 0.12$ & $26.6 \pm 0.9$ & $17.5 \pm 2.6$ & -26.2 & -17.1 \\
\hline AM4 & $3.34 \pm 0.20$ & $2.10 \pm 0.26$ & $1.59 \pm 0.07$ & $26.6 \pm 0.4$ & $15.0 \pm 2.6$ & -25.6 & -14.3 \\
\hline OM4 & $3.24 \pm 0.31$ & $2.49 \pm 0.16$ & $1.75 \pm 0.00$ & $0.13 \pm 0.04$ & $0.07 \pm 0.05$ & 1.1 & 0.8 \\
\hline \multicolumn{8}{|c|}{ Expt II (clam and polychaete) } \\
\hline AM0 & $0.01 \pm 0.00$ & $0.00 \pm 0.00$ & $0.00 \pm 0.00$ & $39.6 \pm 3.4$ & $5.5 \pm 1.1$ & -39.6 & -5.5 \\
\hline AM1 & $0.09 \pm 0.01$ & $0.03 \pm 0.00$ & $0.03 \pm 0.00$ & $40.4 \pm 2.3$ & $13.7 \pm 1.7$ & -40.3 & -13.7 \\
\hline AM2 & $0.29 \pm 0.01$ & $0.11 \pm 0.01$ & $0.11 \pm 0.02$ & $33.2 \pm 2.5$ & $10.8 \pm 0.7$ & -33.2 & -10.8 \\
\hline AM3 & $1.17 \pm 0.05$ & $0.52 \pm 0.03$ & $0.61 \pm 0.11$ & $31.2 \pm 0.3$ & $4.5 \pm 1.6$ & -30.9 & -4.2 \\
\hline AM4 & $3.21 \pm 0.13$ & $1.48 \pm 0.14$ & $1.26 \pm 0.42$ & $27.7 \pm 1.4$ & $6.3 \pm 1.0$ & -26.9 & -5.7 \\
\hline OM1 & $0.09 \pm 0.01$ & $0.04 \pm 0.01$ & $0.04 \pm 0.01$ & $2.9 \pm 0.1$ & $1.0 \pm 0.2$ & -2.8 & -1.0 \\
\hline OM3 & $1.17 \pm 0.01$ & $0.79 \pm 0.05$ & $0.81 \pm 0.06$ & $0.2 \pm 0.0$ & $0.1 \pm 0.0$ & 0.2 & 0.4 \\
\hline OM4 & $3.04 \pm 0.21$ & $1.59 \pm 0.27$ & $1.04 \pm 0.15$ & $0.03 \pm 0.00$ & $0.03 \pm 0.00$ & 0.8 & 0.5 \\
\hline
\end{tabular}

Table 3. Mean Ag concentrations $(\mathrm{nM})$ in porewater or overlying water in Expt I $(\mathrm{N}=2)$. Ag concentrations of porewater or overlying water in all other treatments of Expts I and II were below detection limit (7.4 nM). na: not available; other abbreviations as in Table 1

\begin{tabular}{|c|c|c|c|c|c|c|c|c|c|c|}
\hline \multirow{3}{*}{ Treatment } & \multicolumn{4}{|c|}{ Porewater } & \multicolumn{6}{|c|}{ Overlying water } \\
\hline & & & & & & UF & & & $\mathrm{SF}$ & \\
\hline & $t=0$ & $t=f$ & $t=0$ & $t=f$ & $t=0$ & $t=5$ & $t=f$ & $t=0$ & $t=5$ & $t=f$ \\
\hline AM4 & 17.1 & 9.3 & na & 11.5 & 7.1 & 9.6 & $<7.4$ & na & 27.3 & 14.9 \\
\hline OM4 & 67.0 & 18.4 & na & 18.9 & 30.3 & 7.4 & $<7.4$ & 36.6 & 15.8 & 12.6 \\
\hline
\end{tabular}

\section{Silver bioaccumulation}

Tissue Ag concentration in both amphipods and clams increased proportionally with the weak-acid extractable Ag in the sediments (Ag-SEM), regardless of oxidation state (i.e. AVS levels) of the sediment (Table 4). A similar relationship was observed in the tissue of the polychaetes, but organisms exposed to oxic sediments accumulated more Ag than those exposed to anoxic treatments when Ag-SEM levels were comparable (Table 4).

Differences in AVS concentrations (oxic versus anoxic) did not significantly influence Ag bioaccumulation in either Leptocheirus plumulosus or Macoma balthica (Fig. 1). In contrast, Neanthes arenaceodentata exposed to the oxic sediments accumulated 2 to $3 \times$ more Ag than those exposed to the anoxic treatments at the same Ag concentration (Fig. 1). All 3 organisms accumulated significantly more Ag than the control organisms even when the Ag-SEM was much less than AVS ([Ag-SEM]/2 - [AVS] <<0) (Fig. 2). Tissue con- centrations of $\mathrm{Ag}$ in $N$. arenaceodentata increased when [Ag-SEM] $/ 2$ - [AVS] > 0 ; but concentrations in $L$. plumulosus and in $M$. balthica did not increase beyond that expected from the relationship with Ag concentrations in the sediments.

Amphipods provided with Ag-contaminated diets accumulated 1.5 to $1.8 \times$ more Ag than those provided with uncontaminated diets. An effect of contaminated diets on Ag bioaccumulation was observed in all test treatments (Fig. 3A). A desorption experiment showed that $<5 \%$ of Ag desorbed from the food with the highest spiked Ag concentration, desorption from the lower spiked Ag concentration was not detected. Tissue Ag in Macoma balthica fed with contaminated algae was not significantly ( $p>0.05)$ different from that in individuals fed uncontaminated algae (Fig. 3B).

Reduction of food ration to one-fifth of the regular ration caused a significant decrease in amphipod body weight after $35 \mathrm{~d}$ exposure; the amphipods fed onefifth of the regular ration weighed $\sim 30 \%$ less than those fed the regular ration (data not shown). These 
Table 4. Leptocheirus plumulosus, Macoma balthica and Neanthes arenaceodentata. Tissue Ag concentrations ( $\mu \mathrm{mol}$ $\mathrm{g}^{-1}$; mean $\pm \mathrm{SD}$ ) in animals exposed to control and to Agspiked sediment and food. na: not available; other abbreviations as in Table 1

\begin{tabular}{|lccc|}
\hline Exposure & $\begin{array}{c}\text { Leptocheirus } \\
\text { plumulosus }\end{array}$ & $\begin{array}{c}\text { Macoma } \\
\text { balthica }\end{array}$ & $\begin{array}{c}\text { Neanthes } \\
\text { arenaceodentata }\end{array}$ \\
\hline \multicolumn{3}{|c}{ Uncontaminated food } \\
AM0 & $0.006 \pm 0.001$ & $0.04 \pm 0.01$ & $0.02 \pm 0.00$ \\
AM1 & $0.019 \pm 0.001$ & $0.07 \pm 0.02$ & $0.05 \pm 0.01$ \\
AM2 & $0.037 \pm 0.003$ & $0.09 \pm 0.02$ & $0.09 \pm 0.01$ \\
AM3 & $0.055 \pm 0.005$ & $0.22 \pm 0.09$ & $0.19 \pm 0.05$ \\
AM4 & $0.090 \pm 0.004$ & $0.47 \pm 0.04$ & $0.61 \pm 0.10$ \\
OM1 & & $0.07 \pm 0.01$ & $0.09 \pm 0.01$ \\
OM3 & $0.091 \pm 0.020$ & $0.21 \pm 0.06$ & $0.42 \pm 0.01$ \\
OM4 & $0.42 \pm 0.12$ & $2.13 \pm 0.16$ \\
Ag-spiked food & & \\
AM1 & $0.029 \pm 0.008$ & $0.06 \pm 0.01$ & na \\
AM2 & $0.066 \pm 0.016$ & & \\
AM3 & $0.100 \pm 0.009$ & $0.24 \pm 0.03$ & na \\
AM4 & $0.144 \pm 0.064$ & & \\
OM4 & $0.134 \pm 0.052$ & & \\
Uncontaminated food (one-fifth ration) & \\
AM0 & $0.004 \pm 0.002$ & & \\
AM2 & $0.047 \pm 0.000$ & & \\
AM3 & $0.056 \pm 0.001$ & & \\
AM4 & $0.158 \pm 0.009$ & & \\
\end{tabular}

differences in food ration and growth rates had little effect on Ag bioaccumulation, except for the treatment with the highest Ag levels in sediment and diet (AM4). In this treatment, tissue Ag concentration was significantly higher when the amphipods received one-fifth of the food ration (Fig. 4).

\section{DISCUSSION}

Benthic animals exposed to metal-contaminated sediments can accumulate metals by ingesting contaminated sediments and other suspended particles, and by exposure to dissolved metals in the overlying water or porewater (Luoma et al. 1992, Wang et al. 1996, Munger \& Hare 1997, Lee et al. 2000a, 2001). However, the relative importance of these routes of exposure can be influenced by biology, sediment geochemistry and/or experimental conditions. In the present experiments, biology was the overriding factor of importance. The polychaete appeared to accumulate more Ag from the dissolved source than from the diet, in accordance with the predictions of equilibrium partitioning, but neither the amphipod nor the bivalve responded in the same way. AVS concentrations in the sediments did not affect the bioavailability of Ag to the amphipods and bivalves. Similarly, the amphipod responded to the presence of
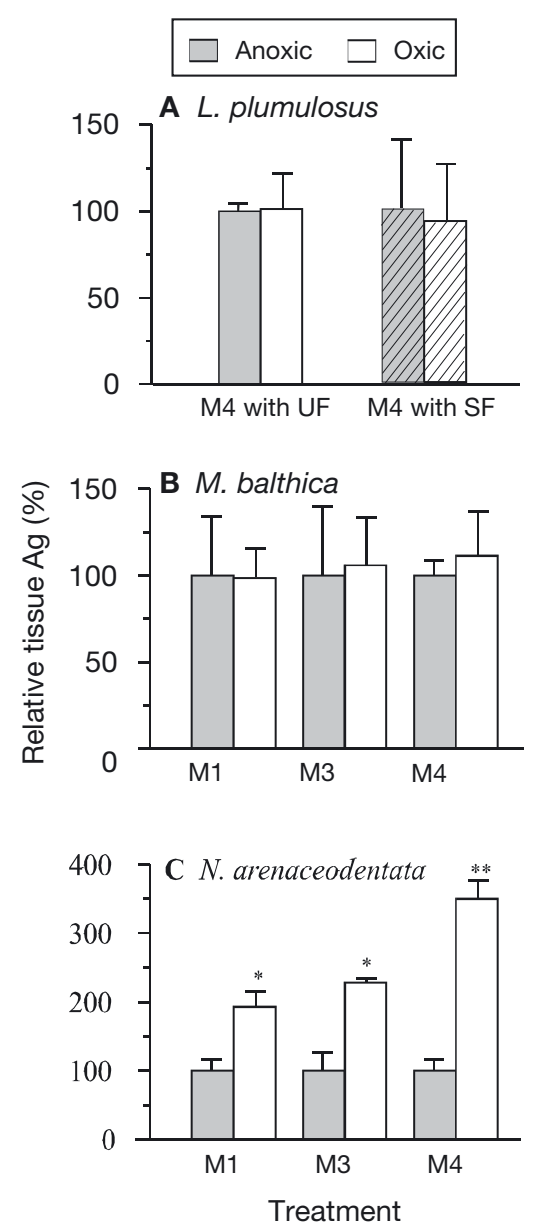

Fig. 1. Leptocheirus plumulosus, Macoma balthica and Neanthes arenaceodentata. Comparison of mean $( \pm \mathrm{SD})$ tissue Ag concentrations in organisms exposed to oxic and anoxic Agspiked sediments. Tissue Ag in oxic sediments was normalized to those in anoxic sediments. M4 with UF, M4 with SF: uncontaminated and metal-contaminated food treatments, respectively. Asterisks represent significant difference in tissue Ag concentration between 2 sediment treatments $(* \mathrm{p}<0.05, * * \mathrm{p}<0.01)$. Error bars indicate standard deviations

supplementary contaminated food with greater Ag bioaccumulation than from sediment alone, but supplementary food had no influence on Ag uptake by the bivalve. Experimental conditions were important, but their importance differed among species. Similarly, geochemistry (AVS concentrations) was critical for the polychaete, but made little difference in chronic exposure of the amphipod and the bivalve. Finally, the outcome of chronic exposure to Ag contaminated sediment was consistent with results predicted by biokinetic models, but was not consistent with predictions of influences on bioavailability from acute toxicity tests.

These findings, that dietary uptake via ingestion of contaminated sediments and food particles was impor- 

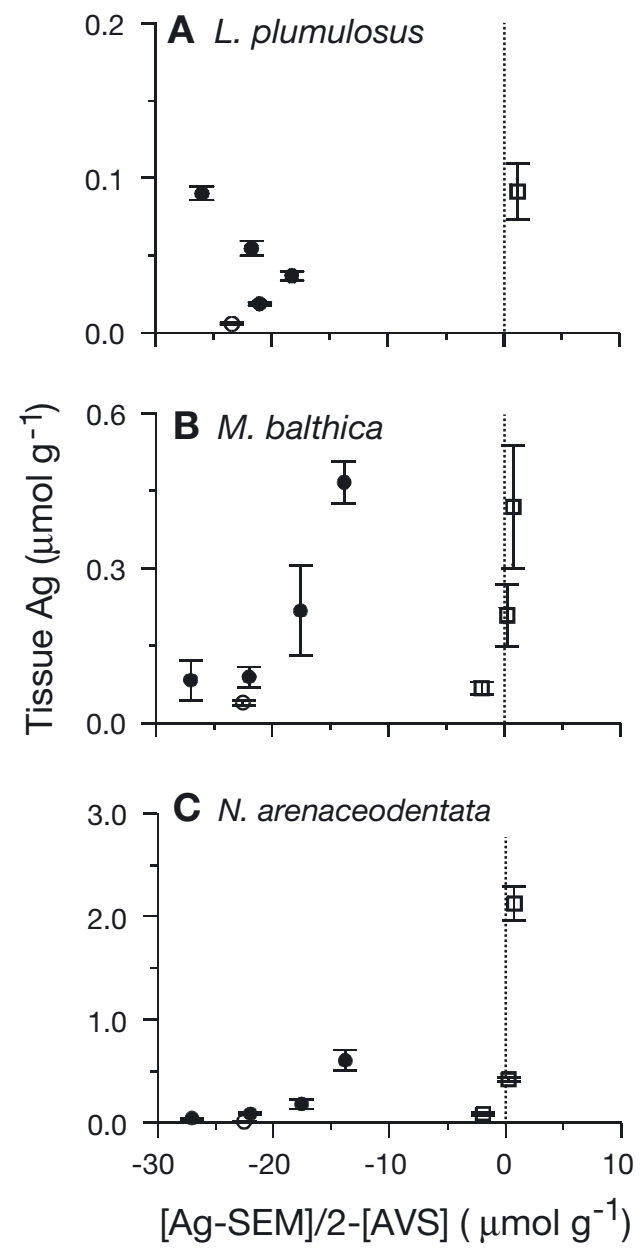

Fig. 2. Leptocheirus plumulosus, Macoma balthica and Neanthes arenaceodentata. Relationship between mean $( \pm \mathrm{SD})$ tissue Ag concentration and [Ag-SEM]/2 - [AVS]. Vertical dotted line marks zero [Ag-SEM]/2 - [AVS] (abbreviations as in Tables $1 \&$ 2). (๑) anoxic-sediment treatments; ( $\square$ ) oxicsediment treatments; (O) uncontaminated control sediment

tant for Ag bioaccumulation, are consistent with those of other studies (Munger \& Hare 1997, Lee et al. 2000a, 2001) demonstrating the dominance of the dietary uptake pathway in metal bioaccumulation by sediment-dwelling organisms in moderately contaminated sediments.

Mechanistically, dietary uptake of Ag by these organisms can be explained by the ingestion of $\mathrm{Ag}$ associated with sediments and food particles and the subsequent assimilation of Ag via gut epithelia into tissue. Numerous studies (Fisher et al. 1995, Wang \& Fisher 1998, Griscom et al. 2000, Lee et al. 2000a, Schlekat et al. 2000) have shown that marine invertebrates can assimilate Ag from various types of food particles, although its assimilation efficiency was generally lower than other elements. In particular, Lee et al. (2000a) demonstrated that Macoma balthica and

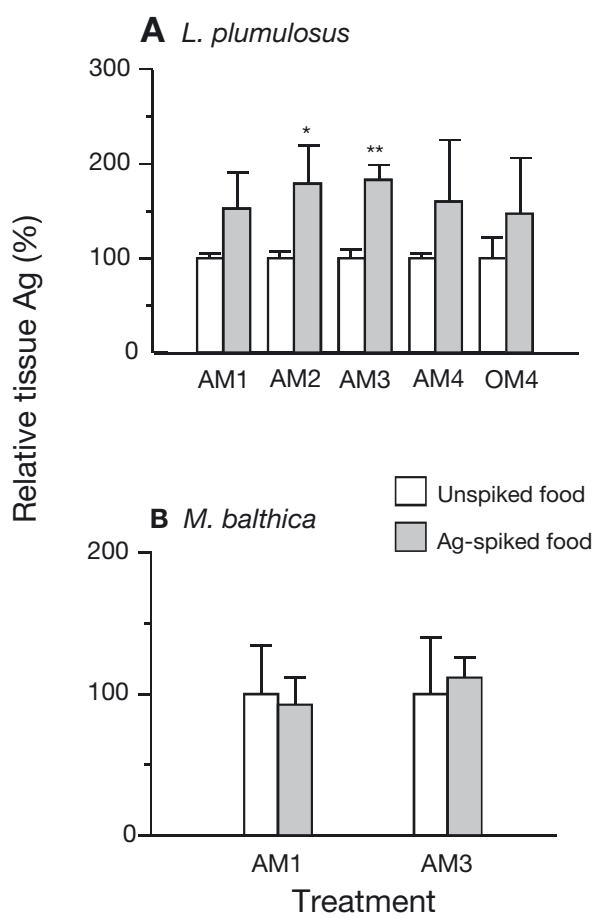

Fig. 3. Leptocheirus plumulosus and Macoma balthica. Comparison of tissue Ag concentrations in organisms exposed to uncontaminated and Ag-contaminated food. Tissue Ag in contaminated-food treatments was normalized to tissue Ag in uncontaminated-food treatments. AM, OM: anoxic and oxic sediments, respectively; asterisks and error bars as in Fig. 1

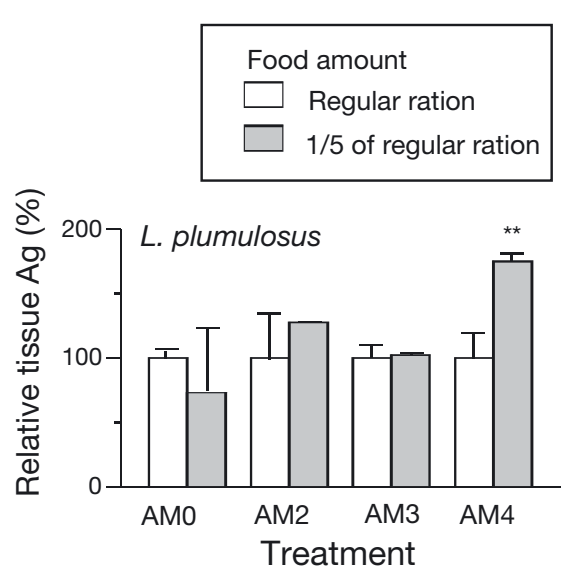

Fig. 4. Leptocheirus plumulosus. Comparison of tissue Ag concentrations in amphipods provided with different amounts of uncontaminated supplementary food. Tissue Ag concentration in treatment with one-fifth of regular ration was normalized to that in treatment with normal ration. Asterisks and error bars as in Fig. 1

Mytilus edulis were able to assimilate Ag by ingestion of both anoxic and oxic particles with similar efficiencies. Later Griscom et al. (2000) reported that Ag assimilation efficiency by $M$. balthica was $20 \pm 5.5 \%$ 
from oxic sediments and $11 \pm 1.7 \%$ from anoxic sediments. The overriding implication is that a portion of the Ag in anoxic sediments is available when ingested by these bivalves, even though silver sulfides in anoxic sediments are the most insoluble forms of metal sulfides (Bell \& Kramer 1999).

Alternatively, a similar geochemical microhabitat created by active burrowing and irrigation of the test organisms may explain the comparable Ag bioaccumulation observed in sediments with high and low AVS treatments. Most benthic animals keep their burrows oxygenated for respiration and to avoid sulfide and ammonia toxicity (Aller 1980, Miron \& Kristensen 1993). Often these oxygenated burrows display geochemical gradients and solute fluxes similar to those in the surface sediment (Aller \& Yingst 1985, Wang et al. 2001). The clam Macoma balthica has a facultative suspension-feeding mode, and the amphipod Leptocheirus plumulosus employs both suspension- and deposit-feeding. Therefore, it is plausible that the test animals in both oxic and anoxic sediments created, and were thus exposed to, a geochemical microenvironment in their burrows that was similar to that of the overlying water, resulting in similar tissue Ag concentrations.

We determined porewater and overlying water Ag concentrations only at the beginning and end of incubation. The detection limit of dissolved Ag (7.4 nM) in the present study was relatively high compared to that in other geochemical studies, but comparable to that in most ecotoxicological studies (e.g. $9.4 \mathrm{nM}$ in Berry et al. 1999) using similar analytical procedures. It is possible that the clam Macoma balthica and the amphipod Leptocheirus plumulosus accumulated Ag from the dissolved source, but we believe that this dissolved Ag source made but a minor contribution to Ag bioaccumulation in these organisms. Numerous previous studies (e.g. Berry et al. 1996, 1999, Lee et al. 2000b) have demonstrated that the dissolved metal concentrations in both overlying water and porewater are controlled by AVS or [SEM-AVS] values. If dissolved Ag in either the porewater or overlying water was a significant source for bioaccumulation in these organisms, then those organisms exposed to oxic sediments should have accumulated more Ag than organisms in anoxic sediments, due to a greater dissolved Ag concentration in the former. The fact that both $M$. balthica and $L$. plumulosus exposed to either oxic or anoxic sediments had similar tissue Ag concentrations suggests that dissolved Ag was not the principal source for Ag bioaccumulation. In contrast, the greater concentration of tissue Ag in Neanthes arenaceodentata exposed to oxic sediments than in those exposed to anoxic sediments was probably due to uptake from comparatively higher dissolved Ag in oxic sediments.
The reasons why porewater Ag had a significant effect only in the polychaetes are not evident. In a study involving exposure of 5 marine benthic invertebrates to Cd-contaminated sediments, Lee et al. (2000a) reported that Neanthes arenaceodentata accumulated significant amounts of $\mathrm{Cd}$ from dissolved sources while the other 4 benthic invertebrates (the bivalves Macoma balthica and Potamocorbula amurensis, and the polychaetes Heteromastus filiformis and Spiophanes missionensis) accumulated $\mathrm{Cd}$ largely from ingested particles. Similarly, Wang et al. (1999) reported that the polychaete Nereis (Neanthes) succinea assimilated dissolved $\mathrm{Ag}$ at the highest rate among the 5 elements ( $\mathrm{Ag}, \mathrm{Cd}, \mathrm{Co}$, Se and $\mathrm{Zn}$ ) tested. They further estimated with a biokinetic model that 5 to $35 \%$ of $\mathrm{Ag}$ in the polychaetes were contributed by the dissolved phase, while most (>98\%) of the other 4 elements were from the dietary pathway. Probably, the greater bioaccumulation of dissolved Ag by the worm could be achieved by uptake via its large body-surface epithelia and well developed parapodia along its elongated body, which function in respiration-gas exchange, and ion-regulation. Alternatively, the greater Ag bioaccumulation in the oxic sediments could be explained if the Neanthes arenaceodentata assimilated Ag with greater efficiency from oxic sediments than from anoxic sediments, as shown for Nereis succinea (Wang et al. 1999).

The elevated Ag bioaccumulation in experiments involving contaminated supplementary diets for amphipods further emphasizes the importance of the dietary pathway. The weight or Ag content of the supplementary food provided to the amphipods comprised only a minute fraction $(<0.2 \%)$ of the total sediments in the test beakers. The results imply that the amphipods selectively fed on the nutritious supplementary diets and accumulated Ag from these diets $(3 \times$ higher $\mathrm{Ag}$ concentration for each sediment treatment). Other studies (Maloney 1996, Schaanning et al. 1996, Lee \& Luoma 1998, Lee et al. 2001) have also shown that some marine invertebrates accumulate considerably more metals by ingestion of organic-rich food particles than by ingestion of organic-poor particles. However, the tissue Ag concentration in Macoma balthica was not affected by Ag contamination levels of the algae, probably due to the lower Ag concentration in the algae (half the total Ag concentration in contaminated sediments).

Unfortunately, the 3 species were exposed not only for different durations (19 versus $35 \mathrm{~d}$ ) but also to Agcontaminated sediment equilibrated for different periods ( 3 versus $5 \mathrm{mo}$ ). These different experimental protocols for different animal species prevented us from evaluating relative bioaccumulation rates (e.g. the bioaccumulation factor) among the 3 test species. 
However, we believe that the different protocols had but a minor influence on the evaluation of the major uptake routes of each test species and the conclusions of this study. We have demonstrated in earlier studies (Lee et al. 2000b, 2004) that porewater metal concentrations decrease most rapidly within 1 mo of equilibration of the metal-spiked sediments, and that partitioning of metals between porewater and sediment change little thereafter. If the different Ag-sediment equilibration times had influenced the partitioning of Ag between the porewater and sediment, and subsequently the Ag bioaccumulation, then the amphipods should have been more exposed to the dissolved source than the clams and polychaetes. However, the bioaccumulation results show that dissolved Ag had only a minor influence on Ag bioaccumulation in the amphipods. Rather, the dissolved Ag source was important only for Ag bioaccumulation in the polychaetes, which were exposed to sediment equilibrated for 5 mo. Further, the dissolved Ag source made but a minor contribution to Ag bioaccumulation in clams exposed to the same sediments as the polychaetes, emphasizing again the importance of the biological processes of each invertebrate species in determining the Ag bioaccumulation pathway.

Overall, the results of this study differ from those of many acute-toxicity tests that have used the AVS normalization approach (Ankley et al. 1996, Berry et al. 1999). Those studies led the authors to conclude that geochemistry is the dominant control on bioavailability and to imply that bioavailability of trace metals (including Ag) from sediments would be negligible when [SEM-AVS] < 0 for all species. In contrast, other studies have also shown that significant bioaccumulation of metals could occur in various benthos exposed to sediments even when [SEM-AVS] < 0. (Hare et al. 1994, Ingersoll et al. 1994, Ankley 1996, Lee et al. 2000c, 2001). Several reasons for such differences have been explained previously (e.g benthic invertebrates ingesting AVS-rich pure-phase particles assimilate metals including Ag; Wang et al. 1999, Griscom et al. 2000, Lee et al. 2000a, 2004). The results of this study emphasize that investigation of the biological mechanisms of uptake is necessary to clarify such dichotomies.

Recently, a growing number of studies have demonstrated that Ag bioaccumulation by some aquatic invertebrates via the food chain or dietary pathway can cause chronic effects, such as reduced fecundity or other reproductive activity (Hook \& Fisher 2001, Hornberger et al. 2001, Bielmyer et al. 2002). Therefore, ecologically relevant risk-assessment and management of Ag-contaminated sediments should consider all the relevant uptake pathways, diverse resident animals with various biological attributes, and a range of toxicological effects expressed in different levels of biological organization ranging from cellular level through individuals to communities.

Acknowledgements. The authors thank 3 anonymous reviewers for thoughtful suggestions. This work was supported by Korea Sea Grant Program from the Ministry of Maritime Affairs and Fisheries.

\section{LITERATURE CITED}

Aller RC (1980) Quantifying the solute distributions in the bioturbated zone of marine sediments by defining an average microenvironment. Geochim Cosmochim Acta 44: 1955-1965

Aller RC, Yingst JY (1985) Effects of the marine deposit-feeders Heteromastus filiformis (Polychaeta), Macoma balthica (Bivalvia), and Tellina texana (Bivalvia) on averaged sedimentary solute transport, reaction rates, and microbial distributions. J Mar Res 43:615-645

Andren AW, Armstrong DE (1999) The environmental chemistry and toxicology of silver. Environ Toxicol Chem 18:1-2

Ankley GT (1996) Evaluation of metal/acid-volatile sulfide relationship in the prediction of metal bioaccumulation by benthic macroinvertebrates. Environ Toxicol Chem 15: $2138-2146$

Ankley GT, Di Toro DM, Hansen DJ, Berry WJ (1996) Technical basis and proposal for deriving sediment quality criteria for metals. Environ Toxicol Chem 15:2056-2066

Arifin Z, Bendell-Young LI (1997) Feeding response and carbon assimilation by the blue mussel Mytilus trossulus exposed to environmentally relevant seston matrices. Mar Ecol Prog Ser 160:241-253

Bell RA, Kramer JR (1999) Structural chemistry and geochemistry of silver-sulfur compounds: critical review. Environ Toxicol Chem 18:9-22

Berry WJ, Hansen DJ, Mahony JD, Robson DL and 5 others (1996) Predicting the toxicity of metal-spiked laboratory sediments using acid-volatile sulfide and interstitial water normalizations. Environ Toxicol Chem 15:2067-2079

Berry WJ, Cantwell MG, Edward PA, Serbst JR, Hansen DJ (1999) Predicting toxicity of sediments spiked with silver. Environ Toxicol Chem 18:40-48

Berthet B, Amiard JC, Amiard-Triquet C, Martoja M, Jeantet AY (1992) Bioaccumulation, toxicity and physico-chemical speciation of silver in bivalve molluscs: ecotoxicological and health consequences. Sci Total Environ 125 :97-122

Bielmyer GK, Bell RA, Klaine SJ (2002) Effects of ligandbound silver on Ceriodaphnia dubia. Environ Toxicol Chem 21:2204-2208

Boothman WS, Helmstetter A (1992) Vertical and seasonal variability of acid volatile sulfides in marine sediments. Research Report. US Environmental Protection Agency, Narragansett, RI

Brown CL, Luoma SN (1995) Use of the euryhaline bivalve Potamocorbula amrensis as a biosentinel species to assess trace metal contamination in San Francisco Bay. Mar Ecol Prog Ser 124:129-142

Bryan GW, Langston WJ (1992) Bioavailability, accumulation and effects of heavy metals in sediments with special reference to United Kingdom estuaries: a review. Environ Pollut 76:89-131

Bufflap WE, Allen HE (1995) Sediment pore water collection methods: a review. Water Res 29:165-177 
Bury NR, Hogstrand C (2002) Influence of chloride and metals on silver bioavailability to Atlantic salmon (Salmo salar) and rainbow trout (Oncorhynchus mykiss) yolk-sac fry. Environ Sci Technol 36:2884-2888

Cain DJ, Luoma SN (1990) Influence of seasonal growth, age, and environmental exposure on $\mathrm{Cu}$ and $\mathrm{Ag}$ in a bivalve indicator, Macoma balthica, in San Francisco Bay. Mar Ecol Prog Ser 60:45-55

Call DJ, Polkinghorne CN, Markee TP, Brooke LT, Geiger DL, Gorsuch JW, Robillard KA (1999) Silver toxicity to Chironomus tentans in two freshwater sediments. Environ Toxicol Chem 18:30-39

DeWitt TH, Redmond MS, Sewall JE, Swartz RC (1992) Development of a chronic sediment toxicity test for marine benthic amphipods. CBP/TRS 89/93. US Environmental Protection Agency, Newport, OR

Di Toro DM, Mahony JD, Hansen DJ, Scott KJ, Carson AR, Ankely GT (1992) Acid volatile sulfide predicts the acute toxicity of cadmium and nickel in sediments. Environ Sci Technol 26:96-101

Fisher NS, Breslin VT, Levandowsky M (1995) Accumulation of silver and lead in estuarine microzooplankton. Mar Ecol Prog Ser 116:207-215

Gorsuch JW, Klaine SJ (1998) Toxicity and fate of silver in the environment. Environ Toxicol Chem 17:537-538

Griscom SB, Fisher NS (2002) Uptake of dissolved Ag, Cd and Co by clam, Macoma balthica: relative importance of overlying water, oxic pore water and burrow water. Environ Sci Technol 36:2471-2478

Griscom SB, Fisher NS, Luoma SN (2000) Geochemical influences on assimilation of sediment-bound metals in clams and mussels. Environ Sci Technol 34:91-99

Hare L, Carignan R, Huerta-Diaz MA (1994) A field study of metal toxicity and accumulation by benthic invertebrates; implication for the acid-volatile sulfide (AVS) model. Limnol Oceanogr 39:1653-1668

Hirsch MP (1998a) Toxicity of silver sulfide-spiked sediments to the freshwater amphipod (Hyalella azteca). Environ Toxicol Chem 17:601-604

Hirsch MP (1998b) Bioaccumulation of silver from laboratoryspiked sediments in the oligochaete (Lumbriculus variegatus). Environ Toxicol Chem 17:605-609

Hogstrand C, Galvez F, Wood CM (1996) Toxicity, silver accumulation and metallothionein induction in freshwater rainbow trout during exposure to different silver salts. Environ Toxicol Chem 15:1102-1108

Hook SE, Fisher NS (2001) Sublethal effects of silver in zooplakton: importance of exposure pathways and implications for toxicity testing. Environ Toxicol Chem 20: 568-574

Hornberger MI, Luoma SN, Cain DJ, Parchaso F, Brown CL, Bouse RM, Wellise C, Thomson JK (2001) Linkage of bioaccumulation and biological effects to changes in pollutants loads in South San Francisco Bay. Environ Sci Technol 34:2401-2409

Ingersoll CG, Brumbaugh WG, Dwyer FJ, Kemble NE (1994) Bioaccumulation of metals by Hyalella azteca exposed to contaminated sediments from the upper Clark Fork River, Montana. Environ Toxicol Chem 13:2013-2020

Janes N, Playle RC (1995) Modeling silver-binding to gills of rainbow-trout (Oncorhynchus mykiss). Environ Toxicol Chem 14:1847-1858

Lee BG, Luoma SN (1998) Influence of mircoalgal biomass on absorption efficiency of $\mathrm{Cd}, \mathrm{Cr}$, and $\mathrm{Zn}$ by two bivalves from San Francisco Bay. Limnol Oceanogr $43: 1455-1466$

Lee BG, Griscom SB, Lee JS, Choi HJ, Koh CH, Luoma SN,
Fisher NS (2000a) Influence of dietary uptake and reactive sulfides on metal bioavailability from aquatic sediments. Science 287:282-284

Lee JS, Lee BG, Luoma SN, Choi HJ, Koh CH, Brown CL (2000b) Influence of acid volatile sulfides and metal concentrations on metal partitioning in contaminated sediments. Environ Sci Technol 34:4511-4516

Lee BG, Lee JS, Choi HJ, Luoma SN, Koh CH (2000c) Influence of acid volatile sulfides and metal concentrations on the bioavailability to marine invertebrates in contaminated sediments. Environ Sci Technol 34:4517-4523

Lee JS, Lee BG, Yoo H, Koh CH, Luoma SN (2001) Influence of reactive sulfide (AVS) and supplementary food on Ag, $\mathrm{Cd}$, and $\mathrm{Zn}$ bioaccumulation in the marine polychaete, Neanthes anrenaceodentata. Mar Ecol Prog Ser 216: 129-140

Lee JS, Lee BG, Luoma SN, Yoo H (2004) Importance of equilibration time in the partitioning and toxicity of zinc in spiked sediment bioassays. Environ Toxicol Chem 23: $65-71$

Luoma SN, Phillips DJH (1988) Distribution, variability and impacts of trace elements in San Francisco Bay. Mar Pollut Bull 19:413-425

Luoma SN, Johns C, Fisher NS, Steinberg NA, Oremland RS, Reinfelder JR (1992) Determination of selenium bioavailability to a benthic bivalve from particulate and solute pathways. Environ Sci Technol 26:485-491

Luoma SN, Ho YB, Bryan GW (1995) Fate, bioavailability and toxicity of silver in estuarine environments. Mar Pollut Bull 31:44-54

Maloney J (1996) Influence of organic enrichment on the partitioning and bioavailability of cadmium in a microcosm study. Mar Ecol Prog Ser 144:147-161

Miron G, Kristensen E (1993) Behavioral responses of three nereid polychaetes to injection of sulfide inside burrow. Mar Ecol Prog Ser 101:147-155

Munger C, Hare L (1997) Relative importance of water and food as cadmium sources to an aquatic insect (Chaoborus punctipennis): implications for predicting Cd bioaccumulation in nature. Environ Sci Technol 31:891-895

Paquin PR, Zoltay V, Winfield RP, Wu KB, Mathew R, Santore RC, Di Toro DM (2002) Extension of the biotic ligand model of acute toxicity to a physiologically-based model of the survival time of rainbow trout (Oncorhynchus mykiss) exposed to silver. Comp Biochem Physiol Part C 133: 305-343

Purcell TW, Peters JJ (1998) Sources of silver in the environment. Environ Toxicol Chem 17:539-546

Reinfelder JR, Chang SI (1999) Speciation and microalgal bioavailability of inorganic silver. Environ Sci Technol 33: 1860-1863

Reinfelder JR, Fisher NS, Luoma SN, Nichols JW, Wang WX (1998) Trace element trophic transfer in aquatic organisms: a critique of the kinetic model approach. Sci Total Environ 219:117-135

Rodgers JA Jr, Deaver E, Rodgers PL (1997) Partitioning and effects of silver in amended freshwater sediments. Ecotoxicol Environ Saf 37:1-9

Sanudo-Willhelmy S, Flegal R (1992) Anthropogenic silver in the southern California bight: a new tracer of sewage in coastal waters. Environ Sci Technol 26:2147-2151

Schaanning MT, Hylland K, Eriksen DO, Bergan TD (1996) Interactions between eutrophication and contamination. II. Mobilization and bioaccumulation of $\mathrm{Hg}$ and $\mathrm{Cd}$ from marine sediments. Mar Pollut Bull 33:71-79

Schlekat CE, Decho AW, Chandler GT (2000) Bioavailability of particle-associated silver, cadmium, and zinc to the 
estuarine amphipod Leptocheirus plumulosus through dietary ingestion. Limnol Oceanogr 45:11-21

US EPA (United States Environmental Protection Agency) (2001) Method for assessing the chronic toxicity of marine and estuarine sediment-associated contaminants with the amphipod Leptocheirus plumulosus. EPA 600/R-01/020. Office of Research and Development, Western Ecology Division, Newport, OR

Wang WX, Fisher NS (1998) Accumulation of trace elements in a marine copepod. Limnol Oceanogr 43:273-283

Wang WX, Fisher NS, Luoma SN (1996) Kinetic determination of trace element bioaccumulation in the mussel Mytilus edulis. Mar Ecol Prog Ser 140:91-113

Editorial responsibility: Otto Kinne (Editor), Oldendorf/Luhe, Germany
Wang WX, Stupakoff I, Fisher NS (1999) Bioavailability of dissolved and sediment-bound metals to a marine depositfeeding polychaete. Mar Ecol Prog Ser 178:281-293

Wang FY, Tessier A, Hare L (2001) Oxygen measurements in the burrows of freshwater insects. Freshw Biol 46:317-327

Warren LA, Tessier A, Hare L (1998) Modeling cadmium accumulation by benthic invertebrates in situ: the relative contributions of sediments and overlying water compartments to organism cadmium concentrations. Limnol Oceanogr 43:1442-1454

Wood CM, Playle RC, Hogstrand C (1999) Physiology and modeling of mechanisms of silver uptake and toxicity in fish. Environ Toxicol Chem 18:71-83

Submitted: June 20, 2003; Accepted: January 8, 2004 Proofs received from author(s): April 2, 2004 